\title{
Some Notes on the Wintering Ecology of Japanese Marsh Warblers, Megalurus pryeri, at Two Sites around Lake Kasumigaura
}

\author{
Hisashi Nagata ${ }^{1}$ and Hoshiko Yoshida ${ }^{2}$ \\ Key words : Megalurus pryeri, Wintering ecology, Population, Mark-and-recapture, \\ Lake Kasumigaura. \\ キーワード：オオセッカ, 越冬生態, 個体群, 標識再捕, 霞ヶ浦.
}

The wintering ecology of the Japanese Marsh Warbler Megalurus pryeri is poorly known, as this species is cryptic and inhabits marsh inaccessible even in winter. Recently, the whereabouts of wintering grounds have been accumulated through a Japan Environment Agency ringing project, though scant wintering records were known before 1970 (Momiyama 1949, Nagata 1997). The warbler winters in reedbeds from Ibaraki to Kagawa Prefecture along the Pacific sea side of central Japan, and there are some passage records in northern part of central Japan, Niigata and Miyagi Prefectures (Nagata 1997). Some authors reported that this warbler wintered and inhabited in dead reeds boggy marsh, where soil was too soft and spongy to allow safe passage (Momiyama 1949, Moyer 1953).

Moyer (1953) reported that a few warblers were observed and captured in 1953 on the north-eastern shore of Lake Kasumigaura. Although the fine marsh along this shore has since disappeared, some warblers were ringed in winter near Tsuchiura and Ukishima along the shore of the lake (Y. Masuda pers. comm., Bird Migration Research Center 1994). Moreover, a new breeding population has established in Ukishima since 1992 (Kanai \& Ueta 1994). To clarify the overwintering ecology of $M$. pryeri, we conducted monthly mist-netting at two study sites along the southern shore of Lake Kasumigaura in winter, 1995/1996.

In this article we report monthly population changes and briefly analyze mark-andrecapture data of the warbler. We think accumulating information of this species' wintering ecology is important for its conservation, despite the small sample sizes included.

\section{Study Sites and Method}

Monthly mist-netting was conducted between November and February in the winter of $1995 / 96$ near the mouth of Seimei River $\left(36^{\circ} 01^{\prime} 46^{\prime \prime} \mathrm{N}, 140^{\circ} 16^{\prime} 59^{\prime \prime} \mathrm{E}\right)$ and in the Ukishima marsh area $\left(35^{\circ} 57^{\prime} 28^{\prime \prime} \mathrm{N}, 140^{\circ} 27^{\prime} 42^{\prime \prime} \mathrm{E}\right)$ (Fig. 1). The Seimei site is situated at

Received 20 February 1997, Revised 11 March 1997, Accepted 19 March 1997.

${ }^{1}$ Laboratory of Wildlife Conservation, National Institute for Environmental Studies, Onogawa 16-2, Tsukuba, Ibaraki 305, Japan. E-mail: hnagata@nies.go.jp

${ }^{2}$ Laboratory of Wildlife Biology, School of Agriculture and Life Sciences, The University of Tokyo, Yayoi 1-1-1, Bunkyo-ku, Tokyo 113, Japan. (Present address: Applied Ornithology Laboratory, National Agriculture Research Center, Kannondai 3-1-1, Tsukuba, Ibaraki 305, Japan. E-mail: hyoshida@narc.affrc.go.jp) 


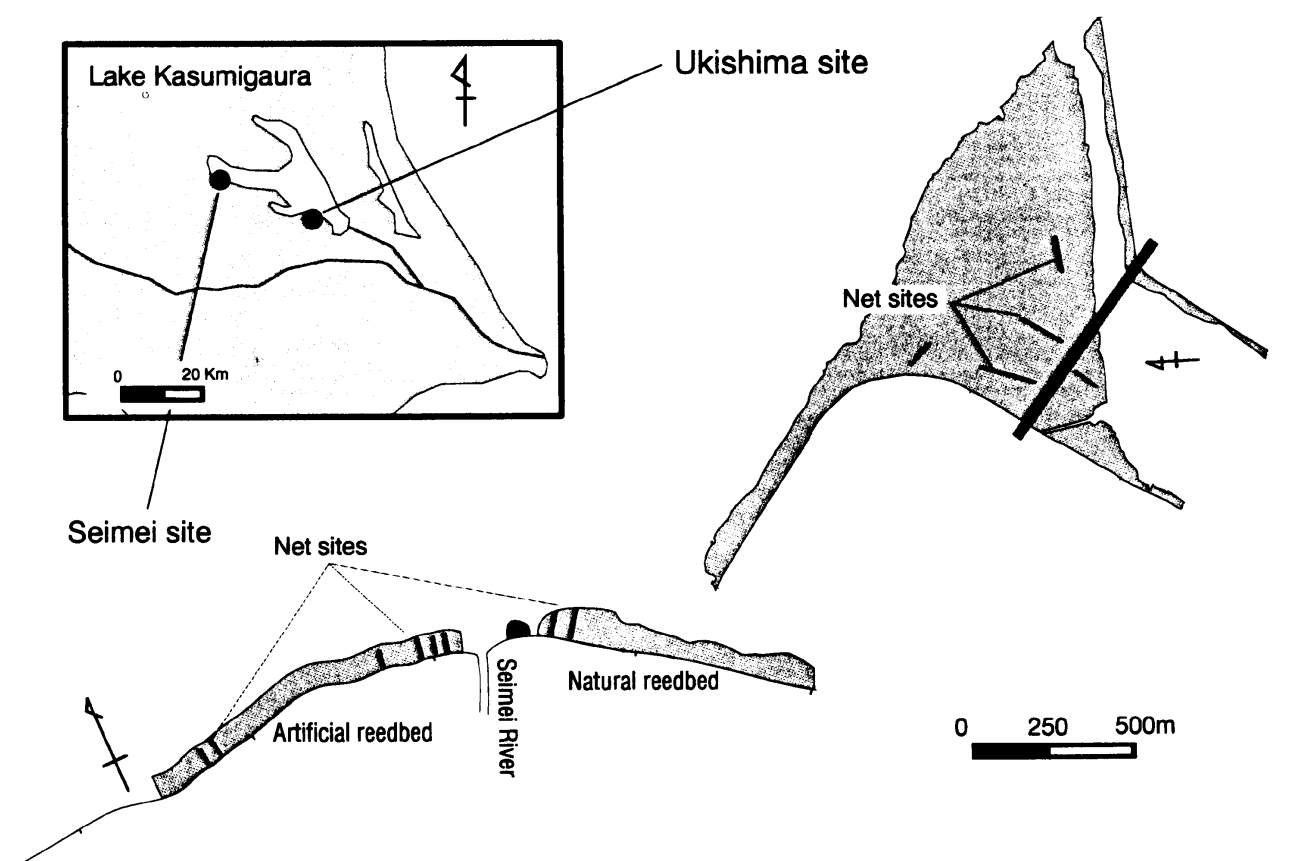

Fig. 1. Map of the study sites.

the southern shore of the lake, $7 \mathrm{~km}$ southeast of Tsuchiura, and Ukishima is situated 18 $\mathrm{km}$ east-southeast of the Seimei site. West of the mouth of the Seimei River reedbeds were made by humans to purify eutrophic lake water. This reedbed is only $40 \mathrm{~m}$ in width, and continues $950 \mathrm{~m}$ along the shore. It is divided into 19 cells delimited by bank piled stone every $50 \mathrm{~m}$; reed Phragmites communis and wildrice Zizania latifolia are planted inside each cell. Natural reedbed stretches to the east of the river-mouth, which is $20-50 \mathrm{~m}$ in width and $600 \mathrm{~m}$ long. This reedbed is covered with reeds, Carex-Phragmites community, cattails Typha latifolia and Z. latifolia, and scattered willow bush Salix sp. from lakeside to bank-side. Ukishima marsh, at 53 ha in area, is the largest marsh along Lake Kasumigaura and supports a rich flora (Michikawa et al. 1992). This marsh is covered with a mainly Carex-Phragmites community and Ischaemum-Phragmites community, and surrounded by dense reedbeds along the shore or creeks. Half to $80 \%$ of dead reed stems are regularly cut or burnt in winter at Ukishima.

We set mist-nets (HTX, $30 \mathrm{~mm}$ mesh $\times 12 \mathrm{~m}$ long) in fixed lines and conducted mist-netting for 3 days in adjacent weeks or the same week at both sites. Eighteen mist-nets were set in 8 lines across reedbeds at the Seimei site. At Ukishima, 24 mist-nets were set along 3 fixed lines every month (Fig. 1), and another 9 mist-nets in 2 lines were set to cover an unburnt area, as almost all netting areas fixed were burnt in February, 1996. All birds captured were ringed, aged, sexed and the netting site recorded before release. We distinguished their age by examining the colour of irises, the skull ossification and existence of juvenile feathers, and sexed them according to the normal sexual dimorphism in wing-length (Shigeta 1991). We pooled all birds captured in the same 
month and ignored birds recaptured within the same month, when we conducted markand-recapture analysis.

\section{Results and Discussion}

Nine and 25 birds were captured at Seimei and Ukishima area, respectively (Table 1). Almost all the birds captured except one at the Seimei site were yearlings. On the other hand, adults, yearlings and even juveniles were captured at Ukishima area (Table 1). The number of captured birds was highest in November at Ukishima area, but there was no such tendency at the Seimei site (Table 1).

Why did these discrepancies occur between study sites? No warblers were breeding at the Seimei site (pers. obs.), but nearly 20 males have established breeding territories in Ukishima marsh since 1992 (WSBJ, Ibaraki branch 1996). The ringing project revealed that the warblers bred in Aomori Prefecture, northern Japan, overwinter in the Kanto area, central Japan, and the population bred in the Kanto area overwinters in southern Kanto to Tokai along the Pacific sea side, though some birds overwinter on their breeding ground (Bird Migration Research Center 1992, 1993, Nagata 1997). As the breeding season of the warbler lasts until September, juveniles fledged or adults bred in September could not complete moulting, and stay at the breeding sites in early November. The migrating population probably originate from the northern breeding population, and some breeding birds might leave and migrate to southern regions from Ukishima. In this case, population exchange and overlap might occur in the Ukishima site.

Ukishima marsh has lasted for more than 65 years, and was known as wintering site for this species since the 1950s (Kiyosu 1965). On the other hand, artificial reedbeds were

Table 1. Number of birds captured at each wintering site

\begin{tabular}{|c|c|c|c|c|c|}
\hline & Nov. 1995 & Dec. 1995 & Jan. 1996 & Feb. 1996 & Total \\
\hline \multicolumn{6}{|l|}{ The Seimei site } \\
\hline Adults & 0 & 0 & 0 & 1 & 1 \\
\hline Yearlings & 3 & 3 & 5 & 4 & 8 \\
\hline Total & 3 & 3 & 5 & 5 & 9 \\
\hline Sex ratio ${ }^{1}$ & 0.33 & 0.67 & 0.20 & 0.80 & 0.44 \\
\hline The proportion of bird recaptured & - & 0.67 & 0.60 & 0.40 & - \\
\hline Estimates of total population ${ }^{2}$ & - & 4.5 & 5.0 & 12.5 & - \\
\hline \multicolumn{6}{|l|}{ The Ukishima site } \\
\hline Adults & 6 & 3 & 3 & 2 & 11 \\
\hline Yearlings & 5 & 3 & 1 & 3 & 11 \\
\hline Juveniles & 3 & 0 & 0 & 0 & 3 \\
\hline Total & 14 & 6 & 4 & 5 & 25 \\
\hline Sex ratio ${ }^{1}$ & 0.18 & 0.33 & 0.00 & 0.60 & 0.27 \\
\hline The proportion of bird recaptured & - & 0.33 & 0.25 & 0.20 & - \\
\hline Estimates of total population ${ }^{2}$ & - & 42.0 & 24.0 & 20.0 & - \\
\hline
\end{tabular}

${ }^{1}$ Sex ratio is the proportion of female numbers to birds captured and sexed.

${ }^{2}$ Estimates of total population from simple one-time recapture model 
Table 2. Occurrence table of individuals in each wintering site

\begin{tabular}{|c|c|c|c|c|c|}
\hline Individual & $\operatorname{sex}$ & Nov. 1995 & Dec. 1995 & Jan. 1996 & Feb. 1996 \\
\hline \multicolumn{6}{|c|}{ The Seimei site } \\
\hline 2J-97883 & $\mathbf{M}$ & $*$ & - $*$ & - & \\
\hline $2 \mathrm{H}-70929$ & $\mathrm{~F}$ & $*$ & $-*$ & 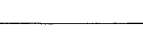 & - $*$ \\
\hline $2 \mathrm{H}-70931$ & $\mathbf{M}$ & $*$ & 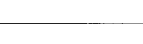 & $-*$ & \\
\hline $2 \mathrm{~K}-13735$ & $\mathrm{~F}$ & & $*$ & $*$ & - $*$ \\
\hline \multicolumn{6}{|c|}{ The Ukishima site } \\
\hline 2F-99708 & $\mathrm{F}$ & $*$ & - $*$ & & \\
\hline $2 \mathrm{H}-70829$ & $\mathbf{M}$ & $*$ & - & & \\
\hline $2 \mathrm{~K}-06704$ & $\mathbf{M}$ & & $*$ & - $*$ & \\
\hline $2 \mathrm{~K}-06789$ & $\mathbf{M}$ & & & $*$ & - $*$ \\
\hline
\end{tabular}

made between 1992 and 1994 at the Seimei site. Two-thirds of the study area was covered with the artificial reedbed, and only one adult bird was captured in natural marsh at the Seimei site. Ralph \& Mewaldt (1975) showed with a displacement experiment that adults are tenacious to their wintering ground across years but some yearlings fix on a new wintering ground. As yearlings disperse more widly than experienced birds in autumn migration (Mead \& Harrison 1979), pioneers of new wintering grounds would be yearlings. The artificial reedbed is a newly established habitat for birds, then the Seimei site might be biased to yearlings.

The proportion of females captured was high in February at both sites (Table 1), but the difference was not significant. Females might arrive later than males in winter. As mist-netting seems to be less effective in capturing females, the number of females may have actually increased in February. Females fly much shorter distances than males when moving within vegetation (pers. obs.).

Four of 9 birds and 4 of 25 birds were recaptured across months at the Seimei and Ukishima sites, respectively (Table 2). The proportion of birds recaptured was two times higher at Seimei than at Ukishima (Table 1). Birds were captured in only two consecutive months at Ukusima, but birds were captured more than twice across 3 to 4 months at the Seimei site (Table 2). The average distance between sites where the same individuals were netted was $30.3 \pm 24.9 \mathrm{~m}($ Mean $\pm \mathrm{SD}, \mathrm{N}=7)$ at Seimei and $100.0 \pm 106.1 \mathrm{~m}(\mathrm{~N}=4)$ at Ukisima. These results show the warbler was site-tenacious and also had a fixed home range within a wintering season. If overwintering birds require the same size of home range as when breeding (e.g. $4100 \mathrm{~m}^{2}$ ) they require an area, $72 \mathrm{~m}$ in diameter. As mist-nets were set in lines with $50 \mathrm{~m}$ intervals on the boundaries of cells of artificial reedbed at the Seimei site, the home range of a warbler might include two netting lines. Mist-nets were set in only 3 lines with 200-250 m intervals at Ukishima, where suitable habitat was burnt in February. Mist-netting across reedbeds might be topographically easy to intercept and capture moving birds at the Seimei site. In this case, birds were captured more effectively at Seimei than Ukishima (Table 1). These are the reasons why the proportion of birds recaptured was less and the duration of birds recaptured was shorter within the wintering season in Ukishima. 
Table 3. Estimates of population parametres at the Seimei site

\begin{tabular}{|c|c|c|c|c|c|c|}
\hline $\begin{array}{l}\text { Month of } \\
\text { ringing }\end{array}$ & $\begin{array}{l}\text { Number of } \\
\text { birds captured } \\
\left(n_{t}\right)\end{array}$ & $\begin{array}{l}\text { Estimates of } \\
\text { total population } \\
\left(N_{t}\right)\end{array}$ & $\begin{array}{l}\text { Estimates of } \\
\text { total population } \\
\text { of birds } \\
\text { ringed }\left(\mathrm{M}_{\mathrm{t}}\right)\end{array}$ & $\begin{array}{l}\text { Estimates of } \\
\text { immigrant } \\
\text { birds }\left(B_{t}\right)\end{array}$ & $\begin{array}{c}\text { Proportion of } \\
\text { birds ringed } \\
\left(\rho_{\mathrm{t}}\right)\end{array}$ & $\begin{array}{l}\text { Proportion of } \\
\text { birds captured } \\
\qquad\left(p_{t}\right)\end{array}$ \\
\hline Nov. 1995 & 3 & 3.0 & & 3.0 & - & - \\
\hline Dec. 1995 & 3 & $8.0 \pm 4.3$ & 6.0 & 2.0 & 0.75 & 0.38 \\
\hline Jan. 1996 & 5 & 14.0 & 9.0 & 3.2 & 0.67 & 0.37 \\
\hline Feb. $\quad 1996$ & 5 & - & - & - & - & - \\
\hline
\end{tabular}

As some birds were captured more than twice at the Seimei site, we estimated population parameters such as total population, number of immigrants and proportion of birds captured from mark-and-recapture data (Jolly 1965). Here, the Jolly-Seber method modified for small sample was applied to the analysis (Ito \& Murai 1977). We used $\mathbf{N}_{1}^{\prime}=\mathrm{n}_{1}$ instead of $\mathbf{N}_{1}^{\prime}=\mathbf{N}_{2}$, as the wintering population started from zero. Estimates of the proportion of birds ringed and captured is $71 \%$ and $37.5 \%$ in average, respectively (Table 3 ). To estimate the total population of the artificial reedbeds we only use estimates from December, as it is more accurate and most birds were captured there. If we assume birds are captured in both sides of a mist-net within $25 \mathrm{~m}$ effectively, it would cover 1.08 ha in area at Seimei. Estimates of density at Seimei were $7.4 \pm 3.9$ birds/ha. Since habitat structure in the artificial reedbed was homogeneous and the artificial reedbed was 3.8 ha in area, we could roughly estimate the total number of birds at $28.1 \pm 14.8$.

In the same manner, we could roughly calculate the total number of warblers using estimates from one-time recapture model at Ukishima. Mist-nets would cover 1.44 ha in area except for February (1.98 ha). As some breeding population might emigrate even in December and suitable habitat shrunk in February, estimates from January, $16.7 \mathrm{birds} / \mathrm{ha}$, were used for calculation. It was almost twice as many as that at Seimei. As the area is huge and vegetation structure is more heterogeneous in Ukishima, it was difficult to estimate the total population of wintering birds. But, at least a hundred and fifty warblers might be wintering at Ukishima marsh, if a quarter of the marsh area is suitable habitat.

The present breeding populations of Japanese marsh warbler are known and the total is estimated at about 1000 birds (Kanai \& Ueta 1994). But the wintering population of the warbler is poorly known. In order to conserve this species, we should locate the wintering ground of all the birds, and preserve these as well as the breeding sites. We can calculate total estimates of the wintering population in Lake Kasumigaura from total area of suitable marsh and our mist-netting data, but such an estimate would not be reliable given our small sample size. Accumulating more data will allow us to make an accurate estimate.

\section{Acknowledgments}

We thank Dr. H. Higuchi, Dr. N. S. Sodhi, Mr. J. Gao, Mr. S. Hotes, Mr. T. Enomoto, Mr. T. Banba, Ms. Y. Umeda, Mr. T. Asano, Mr. Y. Yamaguchi, T. Ichikawa and Mr. A. Gonzalez for field assistance, and Mr. Y. Masuda for giving information. 
Thanks are also due to Dr. R. Hooper for his useful comments on the draft and for his improving our English. We also wish to thank two referees, Dr. K. Ueda and Dr. M. Nakamura, for useful comments.

\section{Reference}

Bird Migration Research Center. 1992. Report of the Bird Migration Research Center 1991 (in Japanese with English summary). Yamashina Institute for Ornithology. Abiko. Chiba.

Bird Migration Research Center. 1993. Report of the Bird Migration Research Center 1992 (in Japanese with English summary). Yamashina Institute for Ornithology. Abiko. Chiba.

Bird Migration Research Center. 1994. Report of the Bird Migration Research Center 1993 (in Japanese with English summary). Yamashina Institute for Ornithology. Abiko. Chiba.

Ito, Y. and Murai, M. 1977. Doubutsu Seitaigaku Kenkyuhou 1. [Methodology in Animal Ecology 1 (in Japanese)]. p. 268. Kokin-shoin, Tokyo.

Jolly, G. M. 1965. Estimates of population parameters from multiple recapture data with both death and dilution-deterministic model. Biometrika 50: 113-128.

Kanai Y. and Ueta, M. 1994. The present distribution and habitat of Japanese Marsh Warbler (in Japanese with English summary) pp. 1-7. In: Survey of the status and habitat conditions of threatened species, 1993. Japan Environment Agency, Tokyo.

Kiyosu, Y. 1965. Nihon Chourui Daizukan 1. [Complete Book of Japanese Birds 1. (in Japanese)], p. 444. Kodan-sha, Tokyo.

Mead, C. J. and Harrison, J. D. 1979. Overseas movements of British and Irish Sand Martins. Bird Study 26: 87-98.

Michikawa, M. Nishihiro, J. and Maeda, O. 1992. Flora of Myogi-no-hana moor at the shore of Lake Kasumigaura (in Japanese with English summary). Tsukuba Environmental Studies 14: 71-78.

Momiyama, T. 1949. Osekka ni tsuite [Notes on Japanese Marsh Warbler (in Japanese)]. Tori 12: 115-143.

Moyer, J. T. 1953. Notes on Bradypterus pryeri from Ibaragi Prefecture. Tori 13: 109-111.

Nagata, H. 1997. Present status of the Japanese Marsh Warbler Megalurus pryeri and its conservation (in Japanese with English summary). J. Yamashina Inst. Ornithol. 29: 27-42.

Ralph, C. J. and Mewaldt L. R. 1975. Timing of site fixation upon wintering grounds in sparrows. Auk 92: 698705.

Shigeta, Y. 1991. Keitai to shikibetu 2. Osekka [Identification guide 2. The Japanese Marsh Warbler; Birds with a vestigial clow on the wing(in Japanese)]. Nihon no Seibutu 5: 48-51.

WSBJ, Ibaraki branch. 1996. Heisei 7 Nendo Shitei-Choju Hogo Chousa Houkoku-Sho [Report on conservation research on endangered wildlife in 1995 (in Japanese)]. Ibaraki Prefecture. Mito.

* Titles in squared parenthesis are translated by the authors.

\section{霞ヶ浦のオオセッカの越冬生態}

霞ヶ浦湖岸の清明川河口と浮島の 2 ヶ所の湿地で, 1995/1996 年の冬期に, 毎月, 決まった場所にかすみ 網をそれぞれ 18 枚および 24 枚を設置し, オオセッカの越冬状況を調查した。調查期間中に, 清明川河口で 9 個体, 浮島で 25 個体のオオセッカが捕獲された。清明川では, 1 歳個体が多く, 同じ場所で何回も再捕さ れ定住性が高い傾向が認められた。また, 両地域とも雌は遅く渡来する傾向が認められた。サンプルサイズ が小さく信頼性は低いが, Jolly 法による個体数推定では $28.1 \pm 14.8$ 個体のオオセッカが清明川河口西岸に 越冬していることが推定された。オオセッカの越冬生態についてはあまり知見がなく，本種の保全のため には越冬個体群を把握することが大切である。 
永田 尚 志：環境庁国立環境研究所地球環境研究グループ野生生物保全研究チーム， テ305 茨城県つくば 市小野川16-2

吉田保志子：東京大学大学院農学生命科学研究科野生動物学教室, 干113 東京都文京区弥生 1-1-1（現所 属：農林水産省農業研究センター病害虫防除部鳥害研究室, 干305 つくば市観音台 3-1-1） 